\title{
Respons Setek Kopi Robusta (Coffea Canephora Pierre Ex Frochner) terhadap Berbagai Konsentrasi Auksin
}

\author{
Response of Robusta Coffee (Coffea Canephora Pierre Ex Frochner) Cutting \\ to Various Auxin Concentrations
}

\author{
Natalia Puspita*, Yan Sukmawan, Dedi Supriyatdi \\ Program Studi Produksi dan Manajemen Industri Perkebunan, Jurusan Budidaya Tanaman Perkebunan, \\ Politeknik Negeri Lampung, Lampung. \\ E-mail: nataliapuspita.nizom25@gmail.com
}

\begin{abstract}
ABSTRAK
Klon kopi robusta (Coffea canephora Pierre ex Frochner) mempunyai keberhasilan setek yang berbedabeda. Upaya mempercepat pertumbuhan setek dapat dilakukan dengan pemberian auksin. Penelitian ini bertujuan untuk mendapatkan konsentrasi auksin terbaik pada pertumbuhan setek kopi robusta klon -BP 308. Penelitian berlangsung selama 4 bulan mulai dari 18 November 2019 hingga 18 Maret 2020 di Kebun Percobaan dan Laboratorium Analisis Politeknik Negeri Lampung. Penelitian menggunakan Rancangan Acak Kelompok (RAK) dengan lima ulangan. Perlakuan yang diterapkan adalah konsentrasi auksin yang terdiri atas $0 \mathrm{ppm}\left(\mathrm{Z}_{0}\right), 100 \mathrm{ppm}\left(\mathrm{Z}_{1}\right), 200 \mathrm{ppm}\left(\mathrm{Z}_{2}\right), 300 \mathrm{ppm}\left(\mathrm{Z}_{3}\right)$, dan $400 \mathrm{ppm}\left(\mathrm{Z}_{4}\right)$. Variabel pengamatan dari penelitian meliputi persentase setek hidup, jumlah daun, volume akar, bobot basah akar, bobot kering akar, bobot basah tajuk, dan bobot kering tajuk. Berdasarkan hasil dan pembahasan dapat disimpulkan bahwa pemberian auksin dengan konsentrasi 300 ppm mampu meningkatkan jumlah daun setek kopi pada 2 BST.
\end{abstract}

Kata kunci: konsentrasi auksin, kopi robusta, setek

\begin{abstract}
Robusta coffee clone (Coffea canephora Pierre ex Frochner) has varying success with cuttings success. Efforts to accelerate the growth of cuttings are carried out by auxin application. This study aims to obtain the best auxin concentration in the growth of BP 308 clone robusta coffee cuttings. The research lasted for 4 months from 18 November 2019 to 18 March 2020 at the Experimental Garden and Analysis Laboratory of the Politeknik Negeri Lampung. The research used a randomized block design (RBD) with five replications. The treatment was auxin concentration consisted of $0 \mathrm{ppm}\left(\mathrm{Z}_{0}\right), 100 \mathrm{ppm}\left(\mathrm{Z}_{1}\right), 200 \mathrm{ppm}$ $\left(Z_{2}\right), 300 \mathrm{ppm}\left(Z_{3}\right)$, and $400 \mathrm{ppm}\left(Z_{4}\right)$. The observation variables of the study included percentage of live cuttings, number of leaves, root volume, root wet weight, root dry weight, shoot wet weight, and shoot dry weight. Based on the results and discussion, it can be concluded that 300 ppm auxin was able to increase the number of coffee cuttings at 2 MAP.
\end{abstract}

Key words: auxin concentration, robusta coffee, cuttings 


\section{PENDAHULUAN}

Tanaman kopi merupakan salah satu jenis tanaman perkebunan yang memiliki potensi cukup besar sebagai penyumbang devisa negara yaitu menempati urutan keempat setelah kelapa sawit, karet, dan kakao. Budidaya kopi di Indonesia sangat menjanjikan karena banyaknya faktor-faktor yang mendukung dalam kegiatan budidaya, mulai dari tersedianya lahan yang cukup hingga tata letak geografis dan iklim yang sesuai. Hal ini diharapkan mampu menghasilkan biji kopi dengan kualitas yang baik (Direktorat Jenderal Perkebunan, 2014). Nilai ekspor kopi yang dihasilkan sebesar lebih dari US\$ 1,4 miliar dan mampu menyerap lapangan kerja lebih dari 1,89 juta kepala keluarga. Dalam kegiatan budidaya ada dua cara yang dapat dilakukan untuk memperbanyak tanaman kopi yaitu dengan cara vegetatif dan generatif.

Perbanyakan secara vegetatif yaitu setek dan sambung pucuk dengan menggunakan bagian tumbuhan mulai dari daun, cabang, dan ranting (Rahardjo dan Pudji, 2012). Kelebihan dari perbanyakan ini antara lain memiliki sifat-sifat yang sama dengan induknya. Usaha yang dapat dilakukan untuk meransang dan mempercepat pembentukan akar serta meningkatkan jumlah akar dan mutu akar adalah dengan pemberian zat pengatur tumbuh (ZPT).

ZPT adalah senyawa organik yang bukan hara (nutrien), secara garis besarnya dapat dibagi atas dua golongan, yaitu alami dan sintetis jika dalam jumlah cukup dapat mendukung pertumbuhan tanaman, namun jika dalam jumlah berlebihan dapat menghambat dan merubah proses fisiologi tumbuhan. ZPT terdiri dari lima yaitu: auksin, giberelin, sitokinin, etilen, dan asam absisat.

Auksin merupakan senyawa dengan ciri-ciri mempunyai kemampuan dalam mendukung terjadinya perpanjangan sel pada pucuk. Menurut Anonim (2012) fungsi auksin dalam pertumbuhan tanaman adalah merangsang pembesaran serta Menurut Anonim (2012) fungsi auksin dalam pertumbuhan tanaman adalah merangsang pembesaran serta pemanjangan sel di daerah meristem ujung. Oleh karena itu, auksin dapat digunakan untuk memicu kecepatan pertumbuhan dalam budidaya tanaman. Hasil penelitian tentang pengaruh penambahan NAA dan Kinetin terhadap pertumbuhan eksplan buah naga mengakibatkan tanaman dapat mengatur derajat pertumbuhan akar dan tunas. Panjang akar suatu tanaman akan berpengaruh terhadap kemampuan tanaman dalam mendapatkan makanan yang ada didalam tanah (Mahadi et al. 2013). Maka perlu dicari konsentrasi zat pengatur tumbuh (auksin) yang optimal dalam meningkatkan pertumbuhan setek kopi.

\section{METODE PENELITIAN}

Penelitian ini dilaksanakan pada 18 November 2019 sampai dengan 18 Maret 2020 di Politeknik Negeri Lampung. Alat yang digunakan dalam penelitian ini adalah pottray dengan diameter lubang atas $5 \mathrm{~cm}$ dan diameter lubang bawah $3 \mathrm{~cm}$ (dimensi pottray $48 \mathrm{~cm} \times 27 \mathrm{~cm} \times 10 \mathrm{~cm}$ dengan isi 45 lubang), kamera, cangkul, gelas ukur, golok, pisau, gunting pangkas, label, meteran, penggaris, jangka sorong, ember, ayakan, gembor, timbangan, dan ATK. Bahan yang digunakan dalam penelitian ini adalah setek kopi robusta klon BP 308 yang terdiri dari ruas 1, 2, dan 3 dari pucuk, Rootone-F, bambu, sungkup plastik, air (sebagai pengencer), media tanam tanah dan arang sekam dengan perbandingan 1:2 yang sudah diayak terlebih dahulu, dan fungisida.

Penelitian ini dilakukan dengan Rancangan Acak Kelompok (RAK) faktor tunggal dengan 5 taraf perlakuan. Setiap perlakuan diulang sebanyak 5 kali sehingga penelitian ini terdapat 25 satuan percobaan. Setiap satuan percobaan terdiri atas 3 tanaman sehingga jumlah secara keseluruhan yaitu 75 setek. Perlakuan yang diterapkan adalah konsentrasi Rootone-F : $0\left(Z_{0}\right), 100$ ppm $\left(Z_{1}\right), 200$ ppm $\left(Z_{2}\right)$, 
$300 \mathrm{ppm}\left(\mathrm{Z}_{3}\right)$, dan $400 \mathrm{ppm}\left(\mathrm{Z}_{4}\right)$. Analisis data dilakukan dengan sidik ragam (uji F) pada taraf nyata 5\%, jika terdapat perbedaan yang signifikan dilanjutkan dengan uji Beda Nyata Terkecil (BNT). Variabel yang diamati meliputi persentase setek hidup, jumlah daun, volume akar, bobot basah akar, bobot kering kar, bobot basah tajuk, dan bobot kering tajuk. Pengamatan dilakukan setiap bulan.

\section{HASIL DAN PEMBAHASAN}

\section{Persentase Setek Hidup (\%)}

Tabel 1. Pengaruh berbagai konsentrasi auksin pada persentase setek hidup (\%) pada 1 BST

\begin{tabular}{lc}
\hline \multicolumn{1}{c}{ Perlakuan } & Rerata setek hidup (\%) \\
\hline$Z_{0}(0 \mathrm{ppm})$ & 98 \\
$\mathrm{Z}_{1}(100 \mathrm{ppm})$ & 100 \\
$\mathrm{Z}_{2}(200 \mathrm{ppm})$ & 100 \\
$\mathrm{Z}_{3}(300 \mathrm{ppm})$ & 100 \\
$\mathrm{Z}_{4}(400 \mathrm{ppm})$ & 96 \\
\hline
\end{tabular}

Tabel 1 menunjukkan bahwa aplikasi Rootone-F pada setek kopi belum mampu memberikan pengaruh pada persentase setek hidup. Hal ini diduga karena Rootone-F, belum mampu untuk mempercepat pembentukan kalus sehingga ada setek yang sudah berkalus namun tidak berkembang menjadi akar. Hal ini menyebabkan cadangan makanan pada bagian batang setek habis, sebelum terbentuknya akar karena diserap oleh tunas.

Terbentuknya akar pada setek merupakan salah satu faktor penting untuk kelangsungan hidup setek karena akar berfungsi untuk menyerap unsur hara, air dan memperkokoh berdirinya setek pada media tanam. Pembentukan akar terjadi pada bakal akar yang terdapat di primodia akar dan kalus. Kalus merupakan jaringan yang terbentuk karena adanya respons tumbuhan untuk menutupi luka pada tumbuhan. Apabila ZPT yang telah diaplikasikan pada tanaman tersebut mampu mempercepat terbentuknya jaringan kalus, maka dari perlakuan yang diberikan tersebut akan terbentuklah akar. Faktor lain yang menyebabkan tidak berpengaruhnya persentase setek hidup pada bulan pertama setelah penanaman, setek banyak mengalami kematian namun setelah bulan berikutnya tingkat kematian pada setek berkurang hal diakibatkan oleh, rawannya setek mengalami kematian akibat kekeringan atau pembusukan dibagian pangkal setek. Hal ini diduga karena pada masa sebulan awal setek masih mengalami transisi atau peralihan antara kondisi setelah pemotongan pucuk hingga setelah ditanam.

Menurut Tiara et al. (2017), Proses munculnya akar pada setek merupakan faktor penting karena berfungsi untuk menyerap air dari media tanam demi kelansungan hidup setek. Banyak proses yang terjadi dari penutupan luka bekas potongan hingga pembentukan akar adventif. Hal tersebut yang menjadikan masa-masa awal penanaman setek menjadi masa penyesuaian setek dengan lingkungan sehingga rawan terjadinya kematian pada setek karena setek hanya mengandalkan cadangan makanan yang ada dalam setek tersebut apabila akar belum tumbuh. Menurut Danu et al. (2011), terjadinya pembusukan sebelum terbentuknya akar diakibatkan karena setek sudah tumbuh tunas namun tidak diikuti oleh tumbuhnya akar hal ini diduga proses penyembuhan luka pada setek relatif lambat. 


\section{Jumlah Daun}

Pertumbuhan daun sangat berpengaruh terhadap terbentuknya tunas pada setek. Sumber energi yang digunakan untuk pertumbuhan tunas diawal pertumbuhan adalah cadangan makanan yang ada pada bahan setek. Menurut Tukawa et al. (2013), kandungan karbohidrat dan nitrogen yang terkandung dalam setek dan yang diserap akar digunakan sebagai cadangan makanan untuk pertumbuhan tunas dan daun pada setek.

Tabel 2. Pengaruh berbagai konsentrasi auksin pada jumlah daun.

\begin{tabular}{ccccc}
\hline \multirow{2}{*}{ Perlakuan } & \multicolumn{3}{c}{ Waktu Pengamatan } \\
\cline { 2 - 5 } & 1 BST & 2 BST & 3 BST & 4 BST \\
\hline $\mathrm{Z}_{0}(0 \mathrm{ppm})$ & 1,46 & $1,54 \mathrm{bc}$ & 2,00 & 3,16 \\
$\mathrm{Z}_{1}(100 \mathrm{ppm})$ & 1,46 & $1,80 \mathrm{ab}$ & 2,80 & 3,50 \\
$\mathrm{Z}_{2}(200 \mathrm{ppm})$ & 1,40 & $1,74 \mathrm{ab}$ & 2,50 & 3,40 \\
$\mathrm{Z}_{3}(300 \mathrm{ppm})$ & 1,24 & $1,90 \mathrm{a}$ & 3,50 \\
$\mathrm{Z}_{4}(400 \mathrm{ppm})$ & 1,28 & $1,24 \mathrm{c}$ & 2,60 & 3,20 \\
\hline BNT 0,05 & tn & 0,323 & 2,20 & tn \\
\hline
\end{tabular}

Keterangan: Angka-angka yang diikuti oleh huruf yang berbeda pada kolom yang sama menunjukkan hasil berbeda nyata berdasarkan uji BNT pada taraf $\alpha=5 \%$; BST $=$ bulan setelah tanam

Selain itu diduga bahwa setek mampu menyerap ZPT yang diberikan dengan baik pada 2 BST, hal ini diduga bahwa pada 2 BST akar pada setek sudah mulai tumbuh, sehingga ZPT mulai dapat diserap oleh setek. ZPT sendiri hanya bersifat biostimulan, yaitu membantu mempengaruhi pertumbuhan dan perkembangan tanaman, salah satunya mempengaruhi pertumbuhan jumlah daun pada setek. Apabila semua proses fisiologis tanaman telah berjalan baik dan sempurna maka ZPT tidak lagi memberikan pengaruh pada tanaman. Hal ini dapat dilihat pada penelitian saya bahwa pada 3 BST sampai 4 BST pertumbuhan jumlah daun tidak lagi memberikan pengaruh, karena ZPT sudah diserap dan digunakan diawal untuk pembentukan organ baru. ZPT yang sudah diserap atau belum diserap setek mulai hilang karena adanya penyiraman pada setek setelah 1 BST.

Umumnya pembentukan tunas dan daun terjadi karena adanya pembelahan sel meristematik dan berdiferensiasi pada tumbuhan yang dipengaruhi oleh kandungan auksin didalam bahan tanam. Kemampuan setek dalam memunculkan tunas umumnya hanya pada satu nodul saja karena cadangan makanan pada setek masih terbatas. Hal ini sesuai dengan pernyataan Hamzah et al. (2016), bahwa pada awal pertumbuhan setek belum mampu menyerap unsur hara yang ada pada media tanam karena belum memiliki akar. Sehingga pada kondisi ini setek hanya memanfaatkan kandungan cadangan makanan pada bahan setek dengan jumlah yang terbatas, sehingga kemampuan memunculkan tunas baru juga terbatas dan akan berakibat pada jumah daun yang dihasilkan oleh setek. 


\section{Pengaruh Berbagai Konsentrasi Auksin terhadap Volume Akar}

Tabel 3. Pengaruh berbagai konsentrasi auksin pada volume akar.

\begin{tabular}{cc}
\hline Perlakuan & Rerata volume akar $(\mathrm{ml})$ \\
\hline $\mathrm{Z}_{0}(0 \mathrm{ppm})$ & 1,20 \\
$\mathrm{Z}_{1}(100 \mathrm{ppm})$ & 1,50 \\
$\mathrm{Z}_{2}(200 \mathrm{ppm})$ & 1,50 \\
$\mathrm{Z}_{3}(300 \mathrm{ppm})$ & 1,40 \\
$\mathrm{Z}_{4}(400 \mathrm{ppm})$ & 1,80 \\
\hline
\end{tabular}

Terbentuknya akar pada setek merupakan faktor penting dalam perbanyakan tanaman secara vegetatif, karena akar memiliki perananan dalam penyerapan unsur hara pada tanah dan berpengaruh pada pertumbuhan setek. Volume akar juga berhubungan dengan kemampuan ZPT dalam merangsang pembentukan akar yaitu bekerja sama dengan kalus agar dapat tumbuh dan berkembang menjadi akar. Jumlah akar yang terbentuk pada setek diakibatkan oleh terbentuknya kalus pada setek akibat pelukaan yang kemudian berubah menjadi akar. Volume akar akan berpengaruh terhadap kekuatan setek dalam menjerat media tanam dan dalam mencari unsur hara. Besarnya hasil volume akar menunjukkan bahwa respons setek terhadap perlakuan ZPT yang diberikan, semakin besar konsentrasi ZPT yang diberikan pada setek maka volume akar juga akan relatif meningkat.

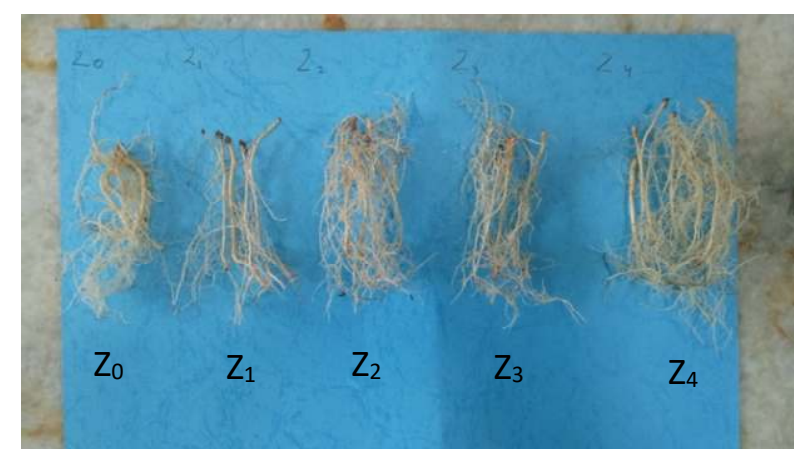

Gambar 6. Penampilan volume akar setek kopi 4 BST

Peningkatan volume akar juga diduga dipengaruhi oleh penggunaan media tanaman arang sekam, karena seperti yang kita ketahui bahwa arang sekam memiliki sifat drainase yang baik serta gembur. Penggunaan pottray juga berpengaruh terhadap volume akar karena terbatasnya ruang untuk pertumbuhan akar jika dibandingkan dengan penanaman pada bedengan. Faktor lain dalam pembentukan perakaran pada setek, yaitu tersedianya air yang cukup untuk setek serta kurangnya penguapan pada daun.

\section{Bobot Basah Akar}


Hasil sidik ragam bobot basah akar (Tabel 21) menunjukkan bahwa perlakuan tidak memberikan pengaruh pada bobot basah akar di akhir penelitian (4 BST). Hasil rata-rata bobot basah akar disajikan pada Tabel 4. Bobot basah akar menunjukkan jumlah bahan organik yang dapat dihasilkan oleh tumbuhan, yang mencakup bobot bersih akar tumbuhan dan jumlah kadar air dalam akar.

Tabel 4. Pengaruh berbagai konsentrasi auksin pada bobot basah akar.

\begin{tabular}{lc}
\hline \multicolumn{1}{c}{ Perlakuan } & Rerata bobot basah akar $(\mathrm{g})$ \\
\hline $\mathrm{Z}_{0}(0 \mathrm{ppm})$ & 1,12 \\
$\mathrm{Z}_{1}(100 \mathrm{ppm})$ & 1,26 \\
$\mathrm{Z}_{2}(200 \mathrm{ppm})$ & 1,28 \\
$\mathrm{Z}_{3}(300 \mathrm{ppm})$ & 1,24 \\
$\mathrm{Z}_{4}(400 \mathrm{ppm})$ & 1,86 \\
\hline
\end{tabular}

Pengukuran berat basah akar ini juga digunakan untuk mengetahui seberapa banyak air yang tekandung dalam akar tanaman tersebut sehingga semakin banyak air yang terkandung dalam akar, maka akan semakin tinggi pula bobot basah akar begitupun sebaliknya. Hal ini sesuai dengan pernyataan Lakitan (2012), bahwa berat basah sangat dipengaruhi oleh kadar air pada jaringan setek, sedangkan bobot kering tanaman dipengaruhi oleh serapan unsur hara serta kandungan cadangan makanan pada setek.

\section{Pengaruh Berbagai Konsentrasi Auksin terhadap Bobot Kering Akar}

Tabel 5 menunjukkan bahwa aplikasi Rootone-F sampai konsentrasi 400 ppm belum mampu meransang pertumbuhan akar secara baik selain itu cadangan makanan yang ada dalam setek juga berpengaruh dalam pembentukan perakaran yang akan berakibat pada meningkatnya bobot kering akar.

Tabel 5. Pengaruh berbagai konsentrasi auksin pada bobot kering akar.

$$
\text { Perlakuan Rerata bobot kering akar }(\mathrm{g})
$$

\begin{tabular}{ll}
\hline $\mathrm{Z}_{0}(0 \mathrm{ppm})$ & 0,12 \\
$\mathrm{Z}_{1}(100 \mathrm{ppm})$ & 0,22 \\
$\mathrm{Z}_{2}(200 \mathrm{ppm})$ & 0,27 \\
$\mathrm{Z}_{3}(300 \mathrm{ppm})$ & 0,20 \\
$\mathrm{Z}_{4}(400 \mathrm{ppm})$ & 0,39 \\
\hline
\end{tabular}

Menurut Hakim et al. (2010), proses pertumbuhan pada tanaman sangat dipengaruhi oleh faktor lingkungan seperti cahaya matahari, air, dan media tanam. Apabila faktor lingkungan tersebut dapat 
dimanfaatkan secara optimal oleh tanaman maka akan memberikan mempengaruhi berat kering akar pada tanaman. Besarnya bobot kering akar sangat berhubungan dengan tingginya volume akar dan banyaknya jumlah akar pada tanaman. Suatu tanaman dapat dikatakan baik apabila berat kering akar yang dimiliki tinggi.

\section{Bobot Basah Tajuk}

Hasil sidik ragam bobot basah tajuk (Tabel 25) menunjukkan bahwa perlakuan tidak memberikan pengaruh pada bobot basah tajuk di akhir penelitian (4 BST). Hasil rata-rata bobot basah tajuk disajikan pada (Tabel 6). Bobot basah tajuk merupakan berat tanaman tanpa akar setelah dipanen dan belum kehilangan air (layu). Peningkatan bobot basah tajuk menunjukkan bahwa setek dapat menyerap unsur hara yang ada pada media tanam yang digunakan untuk memacu pertumbuhan suatu tanaman.

Tabel 6. Pengaruh berbagai konsentrasi auksin pada bobot basah tajuk.

\begin{tabular}{lc}
\hline \multicolumn{1}{c}{ Perlakuan } & Rerata bobot basah tajuk $(\mathrm{g})$ \\
\hline $\mathrm{Z}_{0}(0 \mathrm{ppm})$ & 4,50 \\
$\mathrm{Z}_{1}(100 \mathrm{ppm})$ & 5,28 \\
$\mathrm{Z}_{2}(200 \mathrm{ppm})$ & 5,52 \\
$\mathrm{Z}_{3}(300 \mathrm{ppm})$ & 5,56 \\
$\mathrm{Z}_{4}(400 \mathrm{ppm})$ & 6,50 \\
\hline
\end{tabular}

Bobot basah tajuk tinggi disebabkan oleh jumlah daun yang relatif tinggi. Selain itu adanya faktor lain yaitu ketersediaan unsur hara yang diserap oleh tanaman. Hal ini sesuai dengan pendapat Tatik et al. (2014), semakin tinggi jumlah daun pada tanaman maka semakin tinggi pula bobot basah tajuk yang dihasilkan, karena semakin banyak jumlah daun maka akan berpengaruh terhadap cadangan makanan yang dihasilkan oleh setek.

\section{Bobot Kering Tajuk}

Bobot kering tajuk merupakan hasil bobot kering setelah dioven. Pertumbuhan tanaman dapat diukur dari pertambahan cadangan makanan yang dihasilkan oleh tanaman. Hal ini sesuai dengan pendapat Fitrianah et al. (2012) bahwa bobot kering tajuk merupakan banyaknya cadangan makanan yang dapat diserap oleh tanaman dari hasil proses fotosintesis selama pertumbuhan tanaman, jadi semakin baik pertumbuhan tanaman maka bobot kering tajuk yang dihasilkan pun akan meningkat.

Tabel 7. Pengaruh berbagai konsentrasi auksin pada bobot kering tajuk. 


\begin{tabular}{lc}
\hline \multicolumn{1}{c}{ Perlakuan } & Rerata bobot kering tajuk (g) \\
\hline $\mathrm{Z}_{0}(0 \mathrm{ppm})$ & 3,04 \\
$\mathrm{Z}_{1}(100 \mathrm{ppm})$ & 3,30 \\
$\mathrm{Z}_{2}(200 \mathrm{ppm})$ & 3,60 \\
$\mathrm{Z}_{3}(300 \mathrm{ppm})$ & 3,68 \\
$\mathrm{Z}_{4}(400 \mathrm{ppm})$ & 3,94 \\
\hline
\end{tabular}

\section{KESIMPULAN DAN SARAN}

\section{Kesimpulan}

Berdasarkan hasil penelitian dapat disimpulkan bahwa pemberian ZPT auksin dengan konsentrasi 300 ppm mampu meningkatkan jumlah daun setek kopi pada 2 BST.

\section{Saran}

Sebaiknya dilakukan penelitian lebih lanjut tentang pengaruh pemberian auksin dengan jenis ZPT yang berbeda atau dapat dikombinasikan dengan jenis ZPT lain pada setek kopi serta jangka waktu yang lebih lama dan lebih memfokuskan ke variabel pengamatan tentang perakaran.

\section{DAFTAR PUSAKA}

Anonim. 2012. Penuntun Praktikum Mikrobiologi. Laboratorium Biologi UMS. Surakarta.

Arinasa, I. B. K. Sujarwo, W, and Peneng. 2015. The effect of Rootone-F concentrations and type of culm cuttings on growth of black petung bamboo (Dendrocalamus asper (Schult)). Bamboo Journal. Japan Bamboo Society 29 : 1-9.

Direktorat Jenderal Perkebunan. 2014. Statistik Perkebunan Indonesia: Kopi 2013-2014. Kementerian Pertanian. Jakarta.

Fitrianah, L., Siti dan Yunin. 2012. Pengaruh komposisi media tanam terhadap pertumbuhan dan kandungan saponin pada dua varietas tanaman gondola (Basella $s p$ ). Jurnal Agrovigor 5(1): 3446.

Halupi, R. dan Martini, R. 2013. Pedoman Budidaya dan Pemeliharaan Tanaman Kopi di Kebun Campur. World Argoforestry Centre (ICRAF). Bogor.

Hamzah, Rike, P., dan Siti, N. 2016. Pengaruh Konsentrasi IBA dan Lama Perendaman Terhadap Pertumbuhan Setek Tembesu (Fagraea Fragrans Roxb). Jurnal Penelitian Universitas Jambi Seri Sains 18(1): 69-80. 
Kiptiyah dan Mariyatul. 2015. Upaya Peningkatan Pertumbuhan Setek Kopi Robusta melalui pemberian NAA pada Komposisi Media yang Berbeda. Skripsi. Fakultas Pertanian Universitas Pekalongan. Pekalongan.

Lakitan, B. 2012. Dasar-dasar Fisiologi Tumbuhan. Rajawali Press. Jakarta.

Mahadi, I. S. Wulandari, dan D. Trisnawati. 2013. Pengaruh pemberian NAA dan kinetin terhadap pertumbuhan eksplan buah naga (Hylocereus costaricensis) melaui teknik kultur jaringan secara in vitro. Jurnal Biogenesis 2(9):15-19.

Purdyaningsih, E. 2015. Kajian Pengaruh Pemberian ZPT Terhadap Pertumbuhan Stek Nilam. Balai Besar Perbenihan dan Proteksi Tanaman Perkebunan.

Rahardjo dan Pudji. 2012. Panduan Budidaya Dan Pengolahan Kopi Arabika Dan Robusta. Penebar Swadaya. Jakarta.

Rozen, N., Sutoyo, dan Chairani. 2011. Pematahan dormansi benih aren (Arenga pinnata) dengan pelumuran kulit benih pada suspensi Trichoderma. Jurusan Budidaya Pertanian. Fakultas Pertanian. Universitas Andalas. Padang.

Shofiana. 2013. Pengaruh kompos, pupuk kandang, dan Costum-Bio terhadap sifat tanah, pertumbuhan dan hasil tebu (Saccharum officinarum L.) pada Entisol di Kebun Ngrakah-Pawon, Kediri. Indonesia Green Technology 2(1):45-52.

Tiara., Noli, Z. A., \& Chairul. 2017. Pengaruh konsentrasi IBA terhadap kemampuan berakar setek pucuk Alstonia scholaris (L.) sebagai upaya penyediaan bibit untuk revegetasi. Metamorfosa: Journal of Biological Sciences 4(1): 29-34.

Tukawa, N. D., E. Ratnasari , R. Wahyono. 2013. efektivitas 6-furfuryl amino purine (kinetin) dan 6benzylamino purine (BAP) pada media ms terhadap pertumbuhan eksplan pucuk mahoni (Swietenia mahagoni) secara in vitro. Jurnal LenteraBio 2(1): 63-67.

Tatik, T. Rahayu dan M. Ihsan. 2014. Kajian perbanyakan vegetatif tananaman binahong (Anredera cordifolia (Ten) Steenis) pada beberapa media tanam. Jurnal Agronomika 9(2): 179-188. 